\title{
HERMIA AND THE DARK LADY: FROM PERCEIVED OTHERS TO POTENTIAL EROTIC OBJECTS
}

\author{
CRISTINA DIAMANT \\ Babeş-Bolyai University, Cluj-Napoca
}

\begin{abstract}
The present paper is focused on the figures of the Dark Lady of the sonnets and Hermia from A Midsummer Night's Dream as modes of writing against the Petrarchian ideal. The former is the most explicit of Shakespeare's suite of "dark ladies" (which includes Anne, Kate, Hero, Phoebe, Cleopatra, and Rosaline), while the latter is arguably his least individualised character, yet one that has benefitted from more public attention than most thanks to the generous circulation, continuous adaptation and re-contextualisation of the text. Two useful concepts for the discussion I propose are what Mikhail Bakhtin terms "re-accentuation" and "heteroglossia" as these texts allow different voices to dispute the place and worth of a dark-skinned woman, yet it is precisely by creating a space to voice them all that it creates a possibility to shake up the aesthetic, as well as the literary canon. The ontological status of the Dark Lady and Hermia is also of interest, so that a linguistic and stylistic analysis is carried out in order to highlight how conflicting ideologies attempt to appropriate their image, namely the hegemonic versus the inclusive understandings of what James Hughes calls the "personhood-based theory". The revolutionary aspect brought to the table by Shakespeare is his choice for a transition from the hegemonic perspective to one which judges the two "dark ladies" on their own terms.
\end{abstract}

Keywords: convention, exclusion, re-reading, otherness, person

Motto: "I am as fair now as I was erewhile." (A Midsummer Night's Dream, III.ii. 274)

In a time when reactionary attitudes to globalism are increasingly vocal, we witness the uncanny return of fears against miscegenation. In such a context, rereading Shakespeare is imperative as he offers us the tools to reject "clear and distinct ideas" that make the process of othering possible. Should dark ladies, such as the mysterious one who inspired his sonnets, or Hermia of A Midsummer 
Night's Dream be completely othered? Shakespeare's writings point in the opposite direction, given these figures' centrality in his texts: it is the Dark Lady who is the cause of the poet's high torment and bliss, while A Midsummer Night's Dream is propelled into action by Hermia's refusal of Demetrius. Framing them as "others" would call for seeing them as a threat to the social order, a mark of "pollution" (Mary Douglas) that calls for re-establishing the "ontological hygiene" (Elaine Graham) needed to preserve the safe haven that makes the "white man's burden" (Rudyard Kipling) bearable. Not willing to go away from the inner sanctum, forcing the self to look upon them, they raise issues of exclusion, power, and identity extremely topical in a world with various re-formulated nationalisms, in which identity politics occupy central stage. What is relevant for the present discussion is one of the most revolutionary aspects brought to the table by Shakespeare, namely his choice for a transition from a static, comfortable and comforting understanding of identity to one which judges the two "dark ladies", as vehicles of representation, on their own terms. As such, the present paper will explore a political re-reading that seeks to illuminate the ways in which Shakespeare may help us unlearn the mechanism that makes systematic oppression at the intersection of race and gender possible.

The difference brought on by Shakespeare in literature owes greatly to his "weakness (or genius) for total, unconditional, self-sacrificial love" which, as Ted Hughes argues, "seems a little abnormal in the suite of English poets" (Hughes 59). This ardent authenticity will prove to be incomprehensible posthumously for the readers used to English love poetry which gave way to courtly accomplishment, a kind of "institutionalized dishonesty" (Hughes 59) which held central stage until the Romantic age. Not surprisingly, Shakespeare stands out, speaking of a crude true love for authentic women to a tradition of the conceit. He bluntly contradicts the expectations of his readers even in 1765: Dr Samuel Johnson complains in the preface that "neither his gentlemen nor his ladies have much delicacy, nor are sufficiently distinguished from his clowns by any appearance of refined manners" (Johnson in Vickers

66). Shakespeare's refusal to beautify (thus falsify) his heroines should not be seen as a reduction, but as enriching the readers, who will now have to include in their horizon of expectation a type of wisdom difficult to accept when art is seen as mere cheerful escapism. Unlike the troubadours and Dante, the love he discusses is of "a rawness, an untheologized, surprised, private pain" (Hughes 60 ) and the ladies of his writing are cruel in an altogether different sense. The traditional sonnet brought forward a femininity cruel because of her chaste refusal, while The Dark Lady of the sonnets is rather so because of her merry promiscuity and her Athenian counterpart refuses to subject herself to authority, choosing her own love interest even if it means risking her whole being in the process. 
The implied conflict with a cultural and literary tradition is dealt with in the open in the $130^{\text {th }}$ Sonnet: "My mistress, when she walks, treads on the ground" (line 11). It is not just preferring the flesh and blood woman to the idealised, cold stereotype of femininity, but an actual intertextual reference. Petrarch's $69^{\text {th }}$ Sonnet spoke of an ethereal being, too loosely connected to the real world, since "[s]he did not walk in any mortal way/ But with angelic progress..." (lines 9-10). Shakespeare's irony forces upon us the sudden realisation that this Petrarchian lady, "a bestower of superhuman powers" (Malcon in Evans 81) is, as any stereotype, impersonal since they "tire the hearer with a book of words" (Much Ado about Nothing, I.i 307). While the troubadours discovered in the $12^{\text {th }}$ century romantic love, Shakespeare's decision to write about the warm-blooded woman in the $16^{\text {th }}$ century is just as momentous. Harold Bloom even goes as far as to describe his merit as that of "inventing" the human and dramatising new modes of consciousness. Before him, characters were not followed as they changed their relationship to themselves, but to the gods or God. In his writings, however, "characters develop rather than unfold, and they develop because they reconceive themselves" (Bloom xvii). Individuation is achieved, quite often by "selfoverhearing" and, we may add, this also helps cast doubt on received notions of subjectivity. The importance of re-reading Shakespeare and, in a sense, "rewriting" him since our interpretations inscribe meaning on top of the written word, is that of a tool which can be used to know ourselves better as a culture. After all, "Shakespeare perspectivizes his dramas so that, measure for measure, we are judged even as we attempt to judge" (Bloom 15). Our colouring of the characters is revelatory, so that his writings are the litmus paper we have to constantly return to so as to gain a deeper understanding of our society. His flexibility is remarkable thanks to a nuanced representation that "offers us neither nature nor a second nature, neither cosmos nor heterocosmos" (Bloom 15). Indeed, as put in The Winter's Tale, the art itself is, in a sense, nature. Rereading Shakespeare now calls for a re-accentuation of themes that manage to interpellate us. His tormented adoration for the Dark Lady can be seen as an avant-la-lettre "Black is Beautiful" statement in a context no less troubled than ours, given that he was writing in the midst of an expanding imperialist England. Nowadays, the same sense of entitlement and difference lingers on, but in a postcolonial context. To rediscover Shakespeare's difficult love of flesh and blood women questions the possibilities of representing a double marginally positioned subjectivity: the woman who is also black, a necessary intersectional account of eccentricity and ex-centricity.

Gendering race and racialising gender are, as has been shown time and time again, two interrelated processes. As Edward Said notes, an exoticising perspective is fraught with symbolic meanings: while Asians are seen as submissive and effeminate, people originating from Africa, regardless of gender, 
are misread as aggressive and violent. Gender itself is racialised in the sense of seeing women as second-rate citizens or, in Gayatri Spivak's framework, as subalterns whose power to speak their truth is questionable. This is complicated further in narratives of sexual exploration since, as Joyce Green MacDonald remarked, "sex is the crucible, the 'dark womb' where racially identifiable bodies are made" (MacDonald in Loomba 204). Resisting the cultural urge to needlessly exoticise them or making them into bodies alone, Shakespeare demonstrates a Poesque love that is more than love: it is knowledge of the other, from the tentative to the forceful, a process of ethical dimensions. This is remarkable given that it comes with an un-learning of oppression, which is a combination of privilege and power held over someone else. Naturally, this includes the power to define the other according to one's image to use as a foil that flatters the self and silences the other. Shakespeare's dark ladies are, instead, willful in a way that the stereotypical "angry black woman" cannot afford to be in contemporary representations, and that is unapologetically so. The texts reveal conflicting ideologies in their attempt to appropriate their image, namely the hegemonic versus the inclusive, the latter explainable by appealing to what James Hughes calls the "personhood-based theory". The human subject has always been caught between the ever-fluctuating parameters of nature and nurture, although retaining the possibility of relative flexibility. How important is nature in defining human dignity? The past century has given two answers varying in the extremes, from the Nazis assuming that humanity has everything to do with biology to the Communist regime, which favours a view where man is a tabula rasa that culture either makes or breaks. Nowadays, wary of these, we aim for a balance that is difficult to strike in practice. James Hughes's Citizen Cyborg (2004) contrasts two contemporary undercurrents: a "human-racist" theory derived from the Chart of Human Rights that defines its subjects by genome and a "personhood-based theory" drawing on the $1^{\text {st }}$ amendment of the Declaration of Independence. Significantly, he notes that personhood as a concept was needed to enable abolitionist and suffragist movements to exist in the first place as it was never a question whether women were human beings, just simply whether it was possible for them to reach the self-awareness of mature men. Ironically, while nowadays we have naturalised the idea of "human rights," the longest shelf life was actually that of "personhood-based" theories which have been used to discard marginal subjectivities.

Was Shakespeare a universal genius or is this a case of the Uncanny Valley effect in literature? The greater distance from an author, the more we seem to become aware of the constants that stay true, while recent novels quickly reveal what no longer fits our worldview and minor differences irk us more. Be that as it may, whether it is actual psychological depth or simply his lack of didacticism, Shakespeare's texts are, in the framework proposed by Roland Barthes, more writerly than readerly, requiring a more intimate contact. 
This is in no small part thanks to the heteroglossia (Mikhail Bakhtin) of his writings as opposing views are exposed without explicitly judging them as true or false, but allowing the readers an unprecedented degree of freedom. Moreover, this strategy can be empowering for different subjectivities. What comes to mind is Maya Angelou's 1985 address to the National Assembly of Local Arts Agencies in Washington, when she spoke of her childhood conviction that Shakespeare must have been a black girl given the way in which his extraordinary empathy reached her growing up in the Jim Crow law South, speaking of exclusion as she lived it and also allowing her to voice her experience through his words.

The Dark Lady and Hermia are not only revealed to be "persons" in their own right, but also innovative definitions of beauty. Shakespeare cannot be accused of trying "to wash the Ethiop white," so to speak, to try to have the otherness of blackness effaced. On the contrary, there is something more than such politically-correct acceptance when having one character say in an early play: "Is ebony like her? O wood divine..." (Love's Labour's Lost, IV.iii 247-8). Let us now pause to think of the overtones blackness suggested before the Shakespearean shift. To begin with, it is worth remembering that in medieval theatre blackface was a common practice and even one that was symbolic, suggestive of a representation of evil, rather than used to create an impersonation. Mimesis only came to reclaim the stage later. The Renaissance, as Phillipa Berry has pointed out, also knew several positive connotations to blackness, but these were restricted to humanists such as Marsilio Ficino, Giordano Bruno, and Pico della Mirandola. English society saw different representations and Anthony Gerard Barthelemy observes the widespread practice, between 1585 and 1692, of "pageants, tableaux vivants devoid of action and dialogue, [which] specify the inclusion of 'Negroe boys' or 'beautiful Raven-black negroes' (not just English people in blackface), sitting astride effigies of lions, camels, griffins and unicorns" (Barthelemy in Rackin 75), bodies used as a spectacle and as a surface to inscribe the fantastic. As such, they bordered the line between human curiosities and decorative fetishes. Winthrop Jordan also draws our attention to the fact that, as early as before the $16^{\text {th }}$ century, blackness held meanings as ominous as "deeply stained with dirt, soiled, dirty, foul...Having dark or deadly purposes, malignant; pertaining to or involving death, deadly, baneful, disastrous...iniquitous, atrocious, horrible, wicked...indicating disgrace, censure, liability to punishment etc." (Winthrop in Newman 145). Shakespeare chooses to focus on this monstrous sexuality, and so, both the Dark Lady and Hermia are ill omens. The former will separate the poet from his friend and even cause illness; that the latter and not Helena is in an open conflict with her father is no coincidence: "disobedience against the father's law is merely a prelude to the descent into hell and blackness" (Newman 152). Hence the constant threats of death, both in the city under the Athenian 
law and in the woods, later exorcised by the burlesque of the play of Pyramus and Thisbe. When perceived as monstrous otherness, Hermia will be banned for her difference: “Away, you Ethiope!” (III.ii 257), “Out, tawny Tartar, out!”(III.ii 262). Her lover now regrets what is now to his mind a mistake: "So thou my surfeit and my heresy, / Of all be hated, but the most of me!'(II.ii 141-42). She perceives this sudden change of attitude as an offense to identity, and so asks: "Am I not Hermia? Are you not Lysander? / I am as fair now as I was erewhile" (III.ii 273-4). The Dark Lady is described as "The worser spirit a woman coloured ill" (Sonnet 144 line 4), her vices not being omitted, either: "In nothing art thou black save in thy deeds" (Sonnet 131 line 13), her fault being that she is "the bay where all men ride" (Sonnet 137 line 6).

Besides the issues that lay doubt to their claim of appropriate personhood, their unconventional beauty also demands attention. Sonnet 141 comes to mind, with its clear-headed view of the beloved, noting the "thousand errors" but overpowering them with a love that does not obscure them in merry abandonment of the senses. The Dark Lady is unmeritous because "Thou art as tyrannous, so as thou art" (Sonnet 131 line 1), which is all the more monstrous since she is so even in her blackness, "a state that conventionally should be suppliant, not tyrannical" (Blackmore 249), supposedly accommodating the needs of others. Hermia is "cruel" in love, too, when she warns Lysander not to sleep too close to her in the woods, although Demetrius successfully "[m]ade love to Nedar's daughter, Helena/ And won her soul and she, sweet lady, dotes" (I.i 107-8). The dark ladies are more independent and loving them is dangerous, "as a fever, longing still, / For that which longer nurseth the disease" (Sonnet 1476 lines 1-2) and "slayeth me" (I.ii 190), as Demetrius will put it. Since their beauty is unconventional, the lover and the poet speaking out for him both have to be "of imagination all compact" (V.i 8); the second needs it so as to show a believable image of the lover, who, "all as frantic/ Sees Helen's beauty in a brow of Egypt" (V.i 10-11). Theseus is not the only one to notice how close they are to the lunatic, but the sonneteer will also admit that " $[\mathrm{m}] \mathrm{y}$ thoughts and my discourse as madmen's are/ At random from the truth vainly expressed; / For I have sworn thee fair, and thought thee bright,/ Who art as black as hell, as dark as night" (Sonnet 147 lines 11-14).

The beauty of a dark lady lies somewhere else than in her blackness, for "[i]n faith, I do not love thee with mine eyes, / For they in thee a thousand errors note; / But 'tis my heart that loves what they despise, / Who in despite of view is pleased to dote" (Sonnet 141 lines 1-4). Why the necessity of such a disclaimer, though? Umberto Eco answers this in Inventing the Enemy: "The Negro is ugly. The enemy must be ugly because beauty is identified with good (kalokagathia), and one of the fundamental characteristics of beauty has always been what the Middle Ages called integritas (in other words, having all that is required to be an average representative of a species" (Eco 11). In other words, what otherness 
lacks is precisely this "integritas" and that is why the Other appears to be ugly. This deficiency is noticed, however, only when the Other needs to be excluded. Before the mischief caused by Puck, Hermia is "fair Hermia" and even preferred to Helena's Botticelian beauty. Once values are reversed and Lysander shouts "Who will not change a raven for a dove?" (II.ii114), we are immediately told of Hermia's inadequate height, which is suddenly relevant. She is now "You puppet you!" (III.ii 288), "you dwarf/ You minimus, of hind'ring knot-grass made; / You bead, you acorn" (III.ii 327-30). Helena is very much aware that "Love looks not with the eyes, but with the mind" (I.i 234) and so will create an image of Hermia that should be despised. Not only does she insist on her friend being "little" and "lower," but also refers to an implied opposition between the two when she speaks of herself as having "no gift at all in shrewishness;/ I am a right maid for my cowardice" (III.ii 301-2). Helena is feminine and very much aware of it. Hermia may be "tender in happy love," but she is "hot and militant in anger" (Brooks in Shakespeare CXI), so she possesses some "shrewishness" of her own. No more of the idyllic depiction of their schooldays: Hermia is later described as some sort of demon child, a Katarina that will only later be tamed by her lover, much to the dismay of the father, who sees this as newborn "stubborn harshness" (I.i 38). Irrationality and courage are mingled in Hermia, who will admit, when standing for her choice in love, that "I know not by what power I am made bold" (I.i 107-8). The very same traits will appear unnatural in Helena when she pursues Demetrius as she is the traditional representation of femininity, which "should be woo'd, and were not made to woo" (II.i 242).

"Is black so base a hue?" (Titus Andronicus, IV.ii 71). By the 1550s, a third of London was made up of foreigners, which at the time could mean anything from those of a different race, given the relations between England and Morocco, to people who were simply not born in London, but came from the surrounding rural areas. Indeed, Shakespeare hardly ever uses the word "race" in his plays and even when he does it is to denote region, nationality, and lineage since he wrote before the established biologically-motivated discourse on race. The "brow of Egypt," "tawny Tartar" or "Ethiope," labels thrown at Hermia in the play, were a different flavour of gatekeeping than that reserved for the English not born in London, especially since it was still necessary for Shakespeare to add that Othello was a black Moor, yet one suggestive of exclusion, given the edicts issued by Elizabeth the $1^{\text {st }}$ in 1596 and 1601, not too dissimilar in spirit from the so-called Muslim ban in effect in the United States. One cannot frame relations between individuals without imagining the community which subjects them in both senses of the word, both by judging them according to an agreed common framework and by enabling their subjecthood and recognising their personhood based on how well they manage to perform the accepted images of identity. 
The shared sense of what otherness must have meant was nonetheless skewed by distance, both geographical and affective. The masses' idea of the foreigner was largely derived from travelogues, plays, and sermons, having an inherent moralising quality attached to such portrayals. History is repeated in an almost farcical manner, as the triad of national consolidation, imperialist ambitions of expansion, and obsession with racial and religious purity has returned with a vengeance. A surprisingly useful framework to make sense of the changing attitudes towards the dark-skinned, seen as anything from threatening to a necessary evil and even a fetish, is the animal taxonomy proposed by Jorge Luis Borges. The phantasmatic animal is the one you fear and believe to have supernatural qualities, especially as a malevolent agent interfering with the established order. The economic category is that of creatures you use for your own good, disregarding their own well-being, while the oedipal is the one that, once domesticised, can be accepted in one's comfort zone and live side by side with them. The shortened, tongue-in-cheek explanation given by the author goes like this: the phantasmatic is the one you fear, the economic is the animal you eat, and the oedipal is the animal you watch television with. These categories are fluid in the sense that they can be seen as stages the others traverse until they are accepted as almost-the-same, although this can also work in the other direction. Until reaching the last stage, however, gatekeeping is imposed so as to avoid disturbing the "ontological hygiene" (Elaine Graham). This process is nowhere more evident than in the sonnets, where the Dark Lady is, in turn, feared for her power over men to bring out the uncontrollable desires in them, presented as someone to be used for her sexual favours or adored as someone worth sharing your life with. Hermia, much like present day darkskinned women, experiences the traumatic re-categorisation from the oedipal to the economic or even to the phantasmatic. What makes loving the dark ladies problematic, however, is not only their identities as constructs, but also their performances of the self. Promiscuity or "the will most rank" contrasts deeply the era's obsession with chastity and restraint that permeates everything from conduct books and plays to popular sayings. The desired version of femininity took as little space as possible, both as body and as voice. The four virtues demanded of women were chastity, obedience, piety, and silence. Piety is not the object of A Midsummer Night's Dream thanks to the setting which valorises the pagan past already seen as redeemable. It benefits from being both the privileged source of civilization and from justifying the intrusion of the fairies as a a justifiable interest in folk traditions, serving to solidify national identity. However, the remaining suit is given an ironical treatment, given that, disobedient and vocal as Hermia might be, she remains chaste unlike the dotting Helena.

No matter how difficult, Shakespeare loves his self-contradicting heroines, their paradox speaking out the surprise of the lover faced with such 
bewildering otherness and the unspeakable of their charm. As Eco reminds us, understanding the other means going beyond the cliché without denying radical otherness its existence, as it happens when molding the image of the other in one's own familiar and comforting representation. On the contrary, Shakespeare "may be said to be 'fouling the fair' in contrast to 'Fairing the foul" (Blakemore 251), to be re-thinking the whole system of beauty in the view of one individual that makes him question an entire inherited tradition; the more authentic his meeting the other. "But let's be honest," Eco objects, "[t]hese ways of understanding the enemy are the prerogative of poets, saints, or traitors. Our innermost impulses are of quite another kind" (Eco 21-22). The lover of Shakespeare's dark ladies loves like a saint, despite being aware of the other's faults, yet at the same time with a certain violence, like a Žižekian traitor to the world when accepting to "swear beauty herself is black,/ And all they foul that thy complexion lack" (Sonnet 132 lines 13-14). It is a dangerous beauty because it cannot be ignored, but it necessarily de-structures the calm, reassuring world of the convention. The poet's genius lies in his ability to see them as the goddesses of complete being (Ted Hughes) that they are, with all that is strange (thus defamiliarising) in them and all that is desirable alike. Edward Hubler argues that the portrait of the Dark Lady is regarded "in turn with humor, contentment, rebellion, and revulsion- but never simply or falsely" (Hubler 51, italics mine), an attitude which accounts for a deep and "sympathetic understanding of all varieties of feminine nature, his unquenched ardour, his undying love of women - all this is obvious from beginning to end of his work. [...] Hence the most marvellous gallery of female characters in literature" (Partridge in Cook 144). Another aspect which ensures that Shakespeare's heroines are memorable even when not given much detail is his deep sympathy for the humanity of his characters, elevating them through the special focus given rather than using them to fit a ready-made plot pattern. "His story requires Romans or kings, but he thinks only on men" (Johnson in Norris 66), and so the Dark Lady and Hermia speak not only of the black woman, but of the real, living woman, that cannot be what the sonnet tradition from Petrarch onwards had in mind.

Moreover, not surprisingly, the love for such women must be of an altogether peculiar kind, as well. The lover risks more, as he "submits it [love] quite nakedly [...]. He never makes the slightest attempt to shield it from hurt" (Hughes 59). We can also sense the distance from the love Ovid spoke of when the ladies no longer take up a mask that transforms the natural, cold, and wild woman ("the Amazon") into a desirable woman ("the obeying Amazon"), not showing her true colours, being kind and graceful even when suffering. With Shakespeare, the change is no longer a mimesis of the conceit; it is a mutation both of the lover and of the loved one, all the more radical. In the vein of Martin Buber, one might say that the dark ladies cannot be "tamed" since this would 
reduce them to a That ("Es"), but they must be assimilated as a Thou ("Du") irreducible to the I ("Ich"). Consequently, they are creatures to be described in paradoxes so that conflicting feelings come with the territory. Although disagreeing with Ovid's understanding of women, Shakespeare shares with him the attitude towards love, even at its greatest intensity. As C. S. Lewis highlights in Allegory of Love, Ovid seemingly treated love seriously, when he actually found it ridiculous. In much the same way, Andreas Capellanus, in his famous treaty will address the young and curious Gualterius in the third book, and a careful reading into Shakespeare will reveal him as the wise man that should know all about love precisely because he understands why it does not bring salvation. Shakespeare's reader and Gualterius are shown the mechanics of love and exposed to its fickleness to answer their naïve requests, but the author (more complex in his art) also gives one very good (although cynical) advice, seemingly against his will. Although love should not be taken too seriously, as the inconstancy of the relationships in A Midsummer Night's Dream seems to suggest, it produces serious effects. If, as Capellanus claims in Book 1, chapter IV, "[n]ow it is the effect of love that a true lover cannot be degraded with any avarice. Love causes a rough and uncouth man to be distinguished for his handsomeness; it can endow a man even of the humblest birth with nobility of character; it blesses the proud with humility; and the man in love becomes accustomed to performing many serviced gracefully for everyone " (Capellanus 31 ), it is also to blame for Hermia's change of temper and her transformation from a "lower" "brow of Egypt," which Helena bitterly acknowledges: "Through Athens I am thought as fair as she" (I.i 227). Capellanus, speaking of romantic love, sees it as naturally linked to sight to such a degree that he claims that the blind can love only if the feeling bloomed before the two lost their eyesight. Beauty is in the eye of the beholder and Hermia, too, speaks of sight as "lovers' food" (I.2 223). Shakespeare is once again lampooning tradition, showing that, rather than sight revealing anything significant about one's beloved, man is in truth the blindest in love. Hermia's "I would my father look'd but with my eyes" (I.i 56) is no guarantee for the rightness of her choice. The sonnets, as well, are very much concerned with "love as illusion, as self-deception, as bitterly unreal - in ways that remind us that the world of 'A Midsummer Night's Dream' is not altogether as taintless as it might at first appear" (Blakemore 26). Demetrius, in his inconstancy, is a fine example of how foolish young love can be, and an interesting point made by Judith Cook is that there is no saying in the play that Demetrius has the love juice removed from his eyes. Rather than an oversight, it would seem to suggest that love for a conceit cannot last without the magic to sustain it while love for a warm-blooded woman is more dramatic because it lasts longer.

In his understanding of love, Shakespeare is demonstrably a minority. According to Hughes, the only voices in English literature that bear comparison 
to his sonnets are those "of his own love-smitten heroines declaring their "total, unconditional love," ignoring any apparent change in their beloved, ready to immolate themselves on the subjective truth and loyalty of their love" (Hughes 60). His understanding, from which neither the otherness of the woman nor its possibility to become an erotic object escapes, imposes itself to a tradition that had preferred a neat fiction to the more difficult to digest self-contradicting reality. Dame Ellen Terry, in her lectures of the early 1930s,expressed, as one who performed the many subjectivities on offer in Shakespeare, a sense of what we all, but women more notably, owe to Shakespeare for his portrayal of women as "fearless, high-spirited, resolute and intelligent heroines" (Terry in Cook 144). There is no misogyny per se in Shakespeare, but disenchantment with the human nature as a whole. That is why we must not believe those "who tell you, as I was once told, that Shakespeare had to endow his women with virile qualities because in his theatre they were always impersonated by men. This may account for the frequency with which they masqueraded as boys but I am convinced that it had little influence on Shakespeare's studies of women" (Terry in Cook 144-5). Loving and hating the Dark Lady he had been sketching ever since Tamora in Titus Andronicus, Shakespeare was to speak of her for the last time and almost to forgive her, perhaps because she had died by then.

His dark ladies are neither the goddesses of the traditional sonnets nor the demons of folklore. After all, neither description is true in its extreme simplicity bordering on unwilling caricature. They are, instead, perceived in their sympathetic yet pathetic humanity for which he has so much understanding. Young Hermia, who wants to die if she fails to find Lysander in the woods, is seen for what she is, and Janet Suzman wonders how "only a very great poet could recall how blazingly malleable one is when one is young; the appalling worries; the despair; how passionately one feels about every little thing, how vulnerable. [...] No doubt at all; he loved women; in an Englishman, dare I say it, a rare weakness, and consequently infinitely treasurable" (Suzman in Cook 146). Shakespeare is a great poet and his heroines are truly complete beings, with all "their provocativeness, passion, vengefulness, worthlessness, stupidity and a hundred more qualities [that] are so entirely right from the feminine point of view that they provide a field the most ambitious artist can scarcely hope to cover" (Evans in Cook 145), as Dame Edith Evans points out in an introduction to a booklet on a series on Shakespeare designed for BBC radio in the 1930s. Unlike other authors, Shakespeare does not simply reduce women to what men are not. The endings should not confuse the reader because, even if the stubborn Hermia is brought under Lysander's authority, "the heroines become wives only after they have been shown to be something altogether more singular - because more plural" (Belsey 192).

As shown previously in this paper, the 'dark' heroines we are dealing with are doubly marked as 'women' and 'black': their blackness also marks 
them as doubly deviant from the assigned cultural norm because, as American contemporary race theorists have shown, "whiteness" was culturally constructed as a "blank" category, unmarked and thus supposedly unexamined. Like other unmarked categories, it has a touchstone quality of the normal(ised), against which marked objects can be measured and, of course, are bound to be found deviant, that is, wanting. As such, it is strangely situated outside the very paradigm that it defines and is not overtly compared with anything except other instances of symbolic purity. What is more, undesirable relations are discovered because, in this logic, "their own comparability with one another derives from their distance from the touchstone" (Chambers in Loomba 198). Shakespeare exposes such categories for the cultural performances that they are.

Speaking of the judgment passed due to the distance from the ideal of freedom from corruption, it is interesting to note how dark women are eroticised, reduced to their bodies and to sensuality, while eroticised women are also "blackened," as is the case of Bianca in Othello. She begins to be assigned flaws stereotypically associated with Africans, as suggested by Iago's malicious repeated insinuations in the questions "What, look you pale?" and "Look you pale, mistress?" (Othello, V.i. 104,105). This may happen even against the woman's will to participate in the assumed corruption, as is the case of Lucrece in The Rape of Lucrece who, when fatally stabbed, sees that her blood is, in part, still red, but some of it has blackened because of the non-marital sexual contact, even if it was non-consensual. All this makes Hermia's refusal to give up her virginity all the stranger, as a resistance against further cultural "blackening." Shakespeare does not fail to indicate elsewhere how women can be accused of either being too sexual (Gertrude in Hamlet) or not sexual enough (Isabella in Measure for Measure). Genre convention, too, calls for a specific framing of such experience. Tragedies often began with a woman's erotic initiative, preparing the audience for the inevitable punishment. The only framings that made it socially acceptable were tragedy (if the extremely vocal or the insatiable was punished) or comedy (if she was tamed just in time). Hermia's refusal on the riverside, implicitly contrasted with Helena's earlier submission to Demetrius, is not held against Helena, but becomes a reproach against Hermia much like the one against Isabella as she incites desire without returning it. Her lack of interest is not framed as prudence, but seen as irrational pride. Turning back to the other two plays that show the opposite ends of women's sexual conduct, Gertrude is chastised for being less than human in her untimely appetite, while Isabella despises her brother Claudio when he suggests submitting to Angelo and hurls the label "beast" at him. Given that blackness was thought to denote an incomplete human being, it was usually associated with a lack of restraint, and this is shown in the portrait of the Dark Lady as the bay of all men. What is worth mentioning to contemporary audiences is that the atrocity is not that of the suggested number, but of the very act. As Valerie 
Wayne explains, to the early modern, there was no category between the maiden and the courtesan or the whore (Maguire 92). One such example is provided by Middleton's A Trick to Catch the Old One, where a character is called Courtezan in all the early editions, though the text indicates clearly that she lost her virginity to the hero and slept with no one else. The point of the play was precisely to show how disrespectability itself is a construct, given men's inability to tell the difference between the courtesan and the (fake) widow. We may now understand the tragedy of Helena's loss, as well as the potential for Hermia's if she had submitted by the riverbank. As explained by Dusinberre in Shakespeare and the Nature of Women (1996), such eroticising also implies a classist and gendered aspect, given that "whore" was lower-class, while a "rake" was upper-class (Dusinberre in Stanton 99). Denigration on sexual, political, and racial grounds went together as race, gender, and class positions permeate one another. It should not come as a surprise that Kay Stanton, counting the instances of the word "whore" in the Shakespeare canon, found forty-five instances (Stanton 102), also identifying occasions on which it is used merely to denote a sexually objectified woman. Such an aggressive and negative view of human sexuality is at its most poignant in Othello, where Iago's obscene language denies any redeeming quality of Eros, and Othello is shown as the creature living under the triple sign of blackness, degradedness, and repulsiveness. Here, however, instead of the "black ram/ [that i]s tupping your white ewe" (Othello, I.i. 86-9), what we have is a paradoxical black ewe, a lamb spliced with a sacrificial goat held to two standards impossible to reconcile, expected to fail and chastised even when she does not. Peter Stallybrass's essay, "Patriarchal Territories: The Body Enclosed" (1986), speaks of a constant surveillance of a body thought to be naturally grotesque in the Bakhtinian sense, that is as unfinished and transgressing its own limits (Stallybrass in Rackin 61). This surveillance focused on three areas thought to be interrelated: the mouth, the "lady's parts," and the threshold of the house, suggestive of the desired values of silence, chastity, and domesticity. Once Hermia, although chaste, fails to be silent, she has to flee her home. The reader is given no sense of Hermia's moral superiority over Helena, who gave in to temptation. Instead, we are shown a sense of pity imparted to Helena, who gave her all. Improper womanly conduct in dark ladies, however, is more heavily taxed. Failing to fit the necessary bill excludes them not only from womanhood, thus from the desirability which could motivate the closeness necessary for any knowledge of their character, but from humanness altogether. Both deficiency and excess can spell death for them.

These young women, willful as they are, resist hegemonic readings, but the structures of their society limit their possibilities. The royal marriage of $A$ Midsummer Night's Dream can be read as a problematic foreshadowing of relationships that break apart, as it is "predicated not on one woman's submission to a man, but on the submission of an entire community of self- 
governing women" (Paster 192). Unlike The Tempest, it has no heavy shadow of a past usurpation and betrayal hanging just outside the frame. Instead, its own prehistory is obscured, giving rise to questionable readings. Is the free Amazon to be celebrated or scorned as unruly, the way Hermia is in the beginning? No choice of character is accidental with Shakespeare, and anti-suffragist Emily Perkins Bissell was well-aware of this in 1897 when she published a satire transcript of a fictional "lecture" titled "The Mistaken Vocation of Shakespeare's Heroines". The point of "misplacement" bears repeating here: the plots, the exuberant fictional speaker proposed, are not driven by the actions of the men, but by a deliberate misplacement of female characters given that Hamlet "would have killed the king half an hour after Lady Macbeth came to court" (Bissell in Fleming 21), Macbeth, in his weakness, could have benefitted from having Portia's strong hand to aid him, and Beatrice would have eliminated Othello's "jealousies like a summer cloud, laughing away his suspicions, and teased him out of his authority" (Bissell in Fleming 21).This intentional complication is neither an oversight, nor simply for the sake of creating content to write about; it serves Shakespeare the occasion to tease out the tensions in the fabric of society.

At the time of the play, Elizabeth I was the archimage of the selfgoverning militant woman in need of no man to complete her. During her reign, she was identified with Amazonian personages such as Diana and Britomart because she chose a female community and secured her own succession. The latter is especially suggestive in this respect since, in Edmund Spenser's Faerie Queene, Britomart was a virtuous British warrior maiden who defeated Radigund. By extension, these cast Hippolyta and Titania in a favourable light. As we see, however, the Fairy Queen is tricked and forced to renounce her "caprices" (the demand for the Indian boy). There is something grotesquely farcical about the whole arrangement that echoes in a sense Katarina's treatment in The Taming of the Shrew, although hers benefitted from a framing that made it unclear who tamed whom. This is especially true given Shakespeare's reluctance to leave directions in the screenplay, allowing her final monologue to be acted out either as pious submission or snarky masquerade of the one seemingly going along with a structure while subverting it by actually being the one in control. A Midsummer Night's Dream shows no equal battle of wits, but an unequal power play. There is something suspicious, the play seems to suggest, in having women want to govern themselves without men dictating how that is to happen. The iconic status of Elizabeth I may make us misread the socio-historical context from half a millennium's distance. The Virgin Queen may seem to be the symptom of the enlightened state, yet her central position is not quite that of the epitome, but rather of the exception that is paraded about, overshadowing the unsavoury realities of everyday men and women. It would seem that the adoration for the Amazon Queen is reserved for her alone and no 
other willful women partake in it, as seen in Hermia's choice. What this harkened, perhaps, to Shakespeare's contemporaries, was rather the then already seen as dubious Roman Catholic system which had permitted women to leave behind the marriage-motherhood circuit. As nuns, they were virtually free in their overtly chosen religious submission, in no small part thanks to managing their own shared estate without depending on a man to provide for them. Once the country was given to Protestantism and monastic estates were seized by the state, these gynocentric bubbles were broken down and women, once again, had to look to the marriage-motherhood circuit. According to Reformation dogma, it was the only "godly" path they could take since, following 1 Peter 3:7, they were the weaker vessel, given to temptation. As suggested by Hermia's initial option, marriage was not necessarily desired, but it was deemed by society to be the lesser evil. The young girl, should she reject her betrothed, is given two unappealing options: execution or "to be in shady cloister mew'd,/ To live a barren sister all your life" (I.i 71-72). Actually, Elizabeth I made the latter choice. Strangely enough, neither of the two options is seen to be better than the other, prompting the young girl to flee her destiny at the hands of the state. There is also the very phrase "barren sister" to be kept in mind, as it suggests monstrous autogeneration without reproduction. "Barren" implies the lack of fulfillment both in a physical sense, i. e. not containing any vital essence, and an emotional one.

According to the Protestant ethos, there is no fulfillment outside society and attending to "one's lot" is crucial. This is no Ancient Greek voice, as the play functions as a palimpsest with consecutive writings inscribed on the same surface. The irony of the "barren sister" is that the very idea of community should provide Hermia with fulfillment, especially given her later bemoaning of the lost connection with Helena; however, it appears to be a lesser version of the one offered by life with a man. Instead of falling prey to nostalgia, the play frames the loss of female bonds as a laudable feat that confirms a full coming of age. Even so, these are not completely eradicated, especially in moments of vulnerability, as Titania is suggested to have attended the Indian Votaress on her childbed which also served as a deathbed. Such a community of "gossips" is also behind the dark side of the threat hanging over the end, as the hope for flawless progeny (V.i.387) depends on the midwives' skill, all the more so as such familial fulfillment posed a considerable threat to the bodies of young women. In just a handful of lines, religious and social tensions can be found tied together in a puzzling knot.

Despite being a comedy and thus driven by an underway current leading everything to the end celebrations of weddings, A Midsummer Night's Dream, just as it strives to recuperate the image of the beloved in a dark body, also dispels the romantic illusion from the get-go by allowing a doubt to creep in: is the drive to marriage as natural and stable as it is supposed to be? Surely, 
Hermia would very much like to marry Lysander and she is quite vocal about it, but if unmarried life is as good as death, is marriage a self-assumed choice or so deeply ingrained as to be the only thinkable outcome? Suddenly the ending does not seem all that cheerful, but more of what Mircea Eliade might call a "fall into history." What is curious is that the mythical stage has a vaguely homoerotic feel because of the sensuous imagery associated with Hermia and Helen's early days of virtual sisterhood before their unity is dispelled by socio-cultural pressure. It saddens one to see such lively young girls reduced to stasis by the end and so readers are given every reason to be suspicious of the happy transitions of Hippolyta, Hermia, and Helena, as well as of the miraculous rehabilitation of Titania at the hands of her rather irresponsible husband, who troubles both the natural and supernatural world. Ephesians 5:22-23, demanding wives to obey their husbands as the church is to obey Christ, spawned many approving texts at the time and its traces have still not been completely eradicated. Such a text was William Gouge's treatise 'Particular Duties' in Of Domestical Duties (1626), speaking of the expectation that women should leave behind all pretence of their own good judgment and submit wholly to their fathers and then to their husbands. It was even believed that their virtue was thought to be greater the more they differed in opinions with their husbands but chose to stay silent on the matter and obeyed. As Catherine Belseu muses, it seems that the marriage of true minds did not include in its description equality for women, but it was only a new sense of pliability, framing oneself after the unmarked other.

Let us now return to the image of the Amazon for a moment to see how it nuances the reading of the black girl. Without forgetting how this is a place of power she is supposed to fall from, like Tamora in Titus Andronicus, the conquered savage queen makes way for the civilized white men. Subjugated knowledge is excluded, such as that of Sycorax in The Tempest, who is of lower rank through her gender and race as a witch from Algiers. This movement subtly informs the Shakespearean world. In this context, Hippolyta and Titania are implicitly positioned as a foreshadowing for Hermia's destiny. Should she manage to make an acceptable marriage pact, disobedience against the husband will not be an option. Consequently, Hermia is as caught in-between her rejection of the betrothed, the impossibility of future disobedience, and nostalgic longing for the lost sisterhood, as Titania in her loyalty to Indian Votaress, a loyalty that is forced to end. They used to trade advice (I.i.214-16 and III.ii.198208), but their women's talk has to be silenced in accordance with household books, recalling "this common proverb: 'a maid should be seen and not heard"" (Becon in Paster 251) as found in "The Duty of Maids and Young Unmarried Women" by Thomas Becon, supporting the status quo from Pericles onwards. All the affection is to be redirected to the husbands, which is also why the Indian boy, as a trace of Titania's attachment to his mother, must be displaced by the threatened Oberon. In other words, the young woman is taken up in a world of 
men and not allowed to look back fondly on her past life as an Amazon, much like Titania and Hippolyta. But what inspired the portrayal of the Amazon? Interestingly, Shakespeare's source had a different perspective from the one in A Midsummer Night's Dream. When Plutarch tells the story in "Life of Theseus, "it is no grand conquest, but quite the easy and rather anticlimactic defeat given how naïve the "man-loving" Amazons are made out to be, especially Hippolyta, who is tricked into going aboard his ship. Moreover, Plutarch also leaves her story open-ended, so it is debatable whether she does end up marrying Theseus or if she is discarded and killed so that he may marry Antiopa. The more conventional idea of Amazons that we have, as warring women, is supported by certain writings which informed the general sentiment of the age, such as Sir Walter Raleigh's The History of the World (1614).The Amazons are not simply warring with the Ancient Greeks; they are also found in the new world. In this sense, these unruly and aggressive women made for a barbaric foil to the "proper" Petrarchian women, chaste and silent, never leaving their "home", and served as a centrifugal discourse, taking up the image of the "angry woman" and conflating it with blackness, and thus with radical otherness. The story of their rise and fall served to allay contemporary fears about the destiny of women given to licentiousness and cruelty.

I have already spoken at some length about ideologies not as explicitly political sets of ideas, but as the pre-conscious image-concepts that are the " "lived'....relation to the real" (Althusser in Kavanagh 148). Ideology itself is necessary because, although imaginary, it satisfies one's unconscious need for coherence. It is not an object or an essence in itself, but a mediated relation with reality. We cannot leave it aside, but we can continuously shift our perspective to be aware of our readings being conditioned by it. Shakespeare's constantly changing projections should offer us the tools to do so, expanding our own Theory of Mind so as to be more inclusive. An interesting loop can be observed. While Shakespeare had to forge a means of representation appropriate for a highly heterogeneous audience which represented in itself a variety of loci of power, it should come as no surprise that what had to be a "one size fits all" discourse manages to speak to different positions. Back in 1726, Lewis Theobald remarked that there were few English authors "more the subject of the Ladies Reading" (Theobald in Callaghan 17) than Shakespeare. Such a claim is less a sign of the women's special involvement with Shakespearean texts. Instead, it is an expression of surprise that even women showed him disproportionate appreciation. The wealth of double messages and dramatic ironies available in Shakespearean texts always bears the question "Who is speaking" and even "For/over whom?". Catherine Belsey, when speaking of Rosalind's crossdressing put on stage by a young boy, presents it as a comedy of uncertainty, dramatizing a constantly disrupted femininity through the puns that render masculinity visible once again. The point may be taken further. Together, the 
two voices within the same utterance transgress norms by giving room to antithetical positions and the tension between them, asking the questions "whose fantasy?" and "whose wish fulfillment?". Much Ado about Nothing expresses male fantasies but quickly subverts their position of power by presenting them if only to critique them, which teaches one that, for Shakespeare, lending the stage to someone does not guarantee any sympathy for that particular view. This comes against New Criticism views that literary works exist in some sort of vacuum, and are written without any political intent. As shown previously, Shakespeare's society was heavily divided on a great number of issues, so there was no possibility of picking a topic that was "neutral" or that could be read in an "apolitical" manner. Plays themselves were a charged political statement, especially since in early modern Elizabethan England there was no means of dividing one's relation to the real into neat slices such as the sexual, the political, the religious or the aesthetic. Elizabeth I felt that the marriages which concluded Shakespeare' comedies could be an implicit reproach for her failure to marry. This dynamics is hinted at when Bottom is convinced by Quince to change his performance so as not to risk their lives. In doing so, he chooses one that is deemed to be more class-appropriate, even if less aesthetic. James Kavanagh remarks that the discussion of the workmen is, in truth, a mise-en-abime device that acts as an internal commentary on theatre performance centered on the struggle to preserve the hegemony of the ruling class. In this context, "for $u s$ to assert an effective ability to manipulate their sense of reality, for $u s$ to disrupt their lived relation to the real, would be an unacceptable usurpation of ideological power, restrain its effect, and inscribe in it the marks of our own submission" (Kavanagh 157). Shakespeare is not only all too content to mock their fears in the reactions of the noblemen, but also goes against such selfpreserving comfortable and comforting practices.

Alessandro Serpieri, speaking of the semiotics of Shakespearean drama, identifies the axiological-ideological spaces Shakespeare engages with in his plays to illustrate the dialogical structure that allows him to voice both (Serpieri 128). More specifically, he shows how such a grid is applied to Julius Caesar: Caesar and Anthony inhabit a stable symbolic world-order centred around the power of the one, where names are motivated, while the space of Brutus and Cassius is a syntagmatic world-order of the power of the many, where names are revealed to be arbitrary, superstition is exchanged for scepticism, and passion is replaced by cynicism. Taking on such constructs, Shakespeare nevertheless continuously points at the gaps in the system and exposes its irrationality, thus opening the way to noticing the referential illusion. History itself is dramatised as a clash of models. One can also get the sense of an obsession with "what's in a name" behind all the prodigious signs and bad omens. The flimsy reality and ontological flicker in A Midsummer Night's Dream may be of no less political importance than Julius Caesar, especially if we consider that its central themes 
are issues of desire and obedience, underscored by the underlying threat of death. When trying to sway Hermia's reluctance, Theseus resorts to reminding her of her father's absolute will and that it is he who "should be as god" (I.i 47), which means that his will should overpower hers, so that it is imperative to "[q]uestion your desires"(I.i 67). Even so, she refuses to obey the law, which is spoken out in the voice of the father and "consents not to give sovereignty" (I.i 82).This happens elsewhere in the Shakespearean drama to more tragic effects: Desdemona also denies her father's authority and wishes to choose her own husband. In her case, it is her lover's blackness that is suspicious. Her father, Brabantio, cannot explain her choice for a "lascivious Moor" and attributes it to black magic. Ironically, A Midsummer Night's Dream shows magic being used to make a character love a Petrarchian woman. When the dark-skinned lover is thought to be the active element, a fear of corruption that borders on disgust resurfaces, as it happens when Brabantio thinks of Desdemona and Othello engaged in near-animalistic coupling and speaks of their future offspring as the products of bestiality. In the comedy, however, when discussing marriage, Hermia, thanks to being a young woman, is less problematic and thought to be the passive, receiving element of the union, without threatening to spoil the generations to come. Her blackness only becomes apparent when a jealous Helena cannot understand a preference for the "raven" over the "dove".

Tropes and other Flaubertian "received ideas" may be static in themselves but cultural poaching (Michel de Certeau) allows one to revive them and question them unscrupulously. Meanings can be distorted and the relationship between signified and signifier can be disturbed once more. How can Shakespeare speak to us so convincingly, centuries away, on how to be and how to love a black woman? It is not by detecting an essence, but precisely by escaping univocal readings and by problematising reception. There is no "thing in itself" to be retrieved even by the most careful of his readers. In a sense, Shakespeare's craft can be seen as that illustrated by M. Escher's Drawing Hands: reality and illusion blended together in a Moebius strip, rendering each other possible. His creations are beautiful woven words, yet, like Penelope, he tears them all the same to begin anew. If anything, what makes Shakespeare possible for contemporary audiences is precisely this dynamics of doing and undoing that rejects any crystallization that can run the risk of mortification. Even when merely sketched out, his people come alive with contrasts and energy. We have so much left to learn from Shakespeare as each age re-frames our reception differently and he still refuses to allow us to forget the danger of "othering' and of sollipsization. Going against the age-established "Masculinity does, femininity is" (Winnicott in Rose 117), his radical openness does not allow us to be comfortable, but perhaps that is the very point of literature and we must agree with Jacques Derrida that "[t]he so-called 'thing in itself' is always already a representamen shielded from the simplicity of intuitive evidence...The self- 


\section{CRISTINA DIAMANT}

identity of the signified conceals itself unceasingly and is always on the move" (in Evans 89).Words are dangerous not just as tools to measure the world with but also as weapons, yet words are all we have to give "shape to airy nothing".

\section{Works Cited}

Alexander, Catherine and Stanley Wells (ed.). Shakespeare and Race. Cambridge University Press, 2000. Print.

Back, Les and Solomos John (ed.). Theories of Race and Racism. London: Routledge, 2001. Print.

Belsey, Catherine. "Disrupting sexual difference: meaning and gender in the comedies" in Alternative Shakespeares. Edited by John Drakakis, $2^{\text {nd }}$ edition, London: Routledge, 2002. 169-194. Print.

Bloom, Harold. Shakespeare: The Invention of the Human, New York: Riverhead Trade, 1999. Print.

Buber, Martin. I and Thou, Hong Kong: Hesperides Press, 2008. Print.

Callaghan, Dympna. "Introduction" in A Feminist Companion to Shakespeare. Ed. by Dympna Callaghan, $2^{\text {nd }}$ edition, Oxford: Blackwell, 2016, 1-19. Print.

Cook, Judith. Women in Shakespeare. $2^{\text {nd }}$ edition, Virgin, 1990. Print.

de Grazia, Margareta (ed.). The Cambridge Companion to Shakespeare. Cambridge University Press, 2006. Print.

Douglas, Mary. Purity and Danger. An Analysis of the Concepts of Pollution and Taboo, London: Routledge, 2001. Print.

Eco, Umberto. Inventing the Enemy and other occasional writings. Translated from Italian by Richard Dixon, Boston: Houghton Mifflin Harcourt, 2012. Print.

Elsom, John (ed.). Is Shakespeare Still Our Contempoary?. $2^{\text {nd }}$ reprinting, London: Routledge, 1992. Print.

Evans, Malcom. "Deconstructing Shakespeare's comedies" in Alternative Shakespeares. Edited by John Drakakis, $2^{\text {nd }}$ edition, London: Routledge, 2002, 69-97. Print.

Fleming, Juliet. "The Ladies' Shakespeare" in A Feminist Companion to Shakespeare. Ed. by Dympna Callaghan, $2^{\text {nd }}$ edition, Oxford: Blackwell, 2016, 21-39. Print.

Graham, Elaine. Representations of the Post/human: Monsters, Aliens and Others in Popular Culture, Manchester University Press, 2002. Print.

Howard, Jean and Marion O'Connor (ed.). Shakespeare Reproduced: The Text in History and Ideology. London: Methuen, 1987. Print.

Hubler, Edward. The Sense of Shakespeare's Sonnets, Santa Barbara:Greenwood Press, 1976. Print.

Hughes, James. Citizen Cyborg: Why Democratic Societies Must Respond to the Redesigned Human of the Future, Boulder: Westview Press, 2004. Print.

Hughes, Ted. Shakespeare and the Goddess of Complete Being. London: Faber and Faber, 1993. Print.

Kavanagh, James. "Shakespeare in ideology" in Alternative Shakespeares. Edited by John Drakakis, $2^{\text {nd }}$ edition, London: Routledge, 2002, 146-169. Print.

Legatt, Alexander (ed.). The Cambridge Companion to Shakespearean Comedy. Cambridge University Press, 2006. Print. 
Lewis, C. S. The Allegory of Love: A Study in Medieval Tradition, Oxford: Clarendon Press, 1937. Print.

Loomba, Anita and Martin Orkin (ed.). Post-colonial Shakespeares. London: Routledge, 1998. Print.

Loomba, Ania. "The Great Indian Vanishing Trick - Colonialism, Property, and the Family in A Midsummer Night's Dream" in A Feminist Companion to Shakespeare. Ed. by Dympna Callaghan, $2^{\text {nd }}$ edition, Oxford: Blackwell, 2016, 181-206. Print.

Newman, Karen. " 'And wash the Ethiop white': femininity and the monstrous in Othello" in Shakespeare Reproduced: The Text in History and Ideology. Ed. by Jean Howard and Marion O'Connor, London: Methuen, 1987, 143-163. Print.

Rackin, Phyllis."Misogyny is everywhere" in A Feminist Companion to Shakespeare. Ed. by Dympna Callaghan, $2^{\text {nd }}$ edition, Oxford: Blackwell, 2016, 60-75. Print.

Rose, Jacqueline. "Sexuality in the reading of Shakespeare: Hamlet and Measure for Measure" in Alternative Shakespeares. Edited by John Drakakis, $2^{\text {nd }}$ edition, London: Routledge, 2002, 97-121. Print.

Said, Edward. Orientalism, New York: Pantheon Books, 1978. Print.

Serpieri, Alessandro. "Reading the signs: towards a semiotics of Shakespearean drama", translated byKeir Elam, in Alternative Shakespeares. ed. by John Drakakis, $2^{\text {nd }}$ edition, London: Routledge, 2002. Print.

Shakespeare, William. A Midsummer Night's Dream. Edited by Harold F. Brooks, $2^{\text {nd }}$ revised edition, "The Arden Shakespeare”, London: Methuen\&Co. Ltd, 1979. Print.

Shakespeare, William. The Sonnets. Edited by G. Blakemore Evans with an introduction by Anthony Hecht, Cambridge University Press, 1996. Print.

Spivak, Gayatri Chakravorty. In Other Worlds: Essays in Cultural Politics, London: Routledge, 2006. Print.

Stanton, Kay. "Made to write 'whore' upon? Male and Female Use of the Word 'Whore' in Shakespeare's Canon", in A Feminist Companion to Shakespeare. Ed. by Dympna Callaghan, $2^{\text {nd }}$ edition, Oxford: Blackwell, 2016, 98- 121. Print.

Vickers, Brian (ed.). Shakespeare. The Critical Heritage. Volume 5 (1765-1794), London: Routledge\&Kegan Paul, 1979. Print. 